\title{
EFFECT OF PRE-COOLING AND COLD STORAGE ON SAFE STORAGE PERIOD OF SOME MEDICINAL AND AROMATIC PLANTS
}

\author{
ARAFA, G. K. ${ }^{1}$ and A. A.DEWIDAR ${ }^{2}$ \\ 1. Agr. Eng. Res. Inst., Dokki, Giza, Egypt. \\ 2. Hort. Res. Inst., Dokki, Giza, Egypt.
}

(Manuscript received 14 May 2014)

\begin{abstract}
The present work aims to study and evaluate the effects of pre-cooling process on safe storage period of herb plants stored under cooled room condition. Fresh weight loss, chlorophyll a and b, volatile oil percentage and its components for spearmint (Mentha viridis Linn.) Sage (Salvia officinalis L.) and Thyme (Thymus vulgaris L.) were investigated. The freshly harvested herbs were divided into two parts one was kept without pre-cooling (C1) and the other one was Hydro-cooled (C2) at $5 \pm 1.0^{\circ} \mathrm{C}$ before cold room adjusted storing at temperature of 1,3 and $5{ }^{\circ} \mathrm{C}$ and relative humidity of $98 \%$. The obtained results showed that was a the average $7 / 8$ cooling time of 17.5 min proper cooling time for herbs. The maximum fresh weight losses for Spearmint, Sage and Thyme herb were $15.22,5.60$ and $3.71 \mathrm{~g} / 100 \mathrm{~g}$ fresh herbs for the samples without pre-cooling stored at temperature of $5{ }^{\circ} \mathrm{C}$. While the minimum fresh weight loss of $11.21,3.47$ and $1.55 \mathrm{~g} / 100 \mathrm{~g}$ fresh herbs were obtained for the pre-cooled samples stored at temperature of $1{ }^{\circ} \mathrm{C}$ for Spearmint, Sage and Thyme herbs respectively. There was no difference found between $\mathrm{C} 1$ and $\mathrm{C} 2$ and between the three storage temperatures of 1,3 , and $5^{\circ} \mathrm{C}$ on chlorophyll ' $a$ ' an b for all plants under study. For Spearmint, Sage and Thyme, the maximum percentages of the extracted volatile oil were $0.275,0.279$ and $0581 \%$ respectively which obtained for the pre-cooled herbs stored at $1{ }^{\circ} \mathrm{C}$, while the minimum percentages were $0.196,0.227$ and 0.394 , respectively were obtained for the non pre-cooled herb stored at $5{ }^{\circ} \mathrm{C}$. The maximum safe storage periods were 20, 25 and 27 days for the pre-cooled herbs stored at $1{ }^{\circ} \mathrm{C}$, while the minimum storage periods of 9,12 and 15 days were obtained for the non pre-cooled herb stored at $5{ }^{\circ} \mathrm{C}$ For Spearmint, Sage and Thyme respectively. From the above mentioned results, the spearmint, Sage and Thyme herbs should bepre-cooled at $5{ }^{\circ} \mathrm{C}$ for a period of stored at $1{ }^{\circ} \mathrm{C}$ and $98 \% \mathrm{RH}$ to increase the storage period, quality of oil, and decrease the fresh weight loss.
\end{abstract}

\section{INTRODUCTION}

To preserve quality and prolong the storage life of herbs, it is essential to rapidly cool produce to optimum storage temperature. Studies have shown that precooling greatly increases storage life. Cold storage also slows produce respiration and breakdown by enzymes, slows water loss and wilting, slows or stops growth of decayproducing micro organisms, slows and the production of ethylene, the natural ripening agent. The amount of heat in produce is governed by the temperature around it. The temperature difference between newly harvested produce and its optimum storage temperature is an indicator of field-heat. Rapidly lowering the temperature of 
harvested produce to near storage temperature is known as pre-cooling, or removal of field-heat. Produce is usually pre-cooled to $7 / 8$ or 88 percent of the temperature difference. Additional cooling is limited by the time and energy required to reduce the produce temperature to the optimum storage temperature. The post harvest processes are of crucial important in case of medicinal plants. In Egypt, aromatic plants production must be extended because of our suitable environmental conditions including mild climate and abundance in soil types and especially the reclaimed ones. Pre-cooling by removing field heat from freshly harvested herbs and or fruits reduces microbial activity and gave the best longest storage period, fresh consumption or marketing after harvesting and good marketing quality. Furthermore, this also decreases the ripening rate, diminishes water loss and decay, and thus, helps preserving quality and prolongs shelf life of the herbs, Ferreira et al. (1994) and Reina et al. (1995). Also pre-cooling is the first step in good temperature management. The field heat of a freshly harvested crop-heat the product holds from the sun and ambient temperature-is usually high, and should be removed as quickly as possible before shipping, processing and storage. Pre-cooling is generally a separate operation requiring special equipment and or rooms to maximize the shelf life of the fresh agricultural products including the medicinal and aromatic herbs to be on demand whenever required for a logic period. Yamauchi and Watada (1991) found that degradation of chlorophyll appeared to be regulated through the peroxidase-hydrogen peroxide pathway, which opens the prophyrin ring, thus resulting in a colorless compound. This conclusion was arrived from the analysis of chlorophylls and their metabolites by HPLC, chlorophyll decreased at $25{ }^{\circ} \mathrm{C}$ but not at $1{ }^{\circ} \mathrm{C}$. Cantwell and Reid (1993) found that quality characteristics of fresh coriander herbs include a fresh appearance, uniformity of leaf size, form and colour, characteristics of aroma and flavour, and a lack of defects, such as decay or yellowing which are best maintained by low-temperature and high-humidity storage. Gillies and Tovionen (1995) studied the effect of cooling method and packaging with perforated film on broccoli (Brassica oleracea L.) quality during $2{ }^{\circ} \mathrm{C}$ storage. Hydro-cooling was the most rapid cooling method and resulted in the lowest vapour pressure deficits between the broccoli and the surrounding air. Gomez et al. (1999) assessed weight loss and quality (appearance, aroma and colour) in fresh coriander ( $8 \mathrm{~g}$ packages) stored at 4, 10 and $25^{\circ} \mathrm{C}$ for $2,4,6$ and 8 days. They found that quality parameters decreased as storage temperature increased and storage at $4{ }^{\circ} \mathrm{C}$ is recommended for preserving quality for one week, although weight loss after 8 days at $4{ }^{\circ} \mathrm{C}$ was approximately $50 \%$.

Alvares et al. (2007) on their study on parsley indicated that, hydro-cooling procedure reduced the loss of fresh weight from the leaves in the first 12 hours of storage and maintained the relative water content (RWC) at a high level even after seven days of storage at $5{ }^{\circ} \mathrm{C}$. Visual wilting of leaves was observed when approximately $10 \%$ of the initial fresh weight was lost, which was achieved 30 hours after harvest for the 
control and 42 hours for the pre-cooled bunches. Ebaid et al. (2009) found that both rosemary and marjoram herbs should be per-cooled at $5{ }^{\circ} \mathrm{C}$ and stored at zero ${ }^{\circ} \mathrm{C}$ and $98 \% \mathrm{RH}$ to increase safe storage period for fresh consumption or marketing .precooling process increased the storage period and decreased the fresh weight loss for both rosemary and marjoram herbs. The storage period decreased and the fresh weight loss increased by increasing the storage temperatures from 0 to $6{ }^{\circ} \mathrm{C}$. The average $7 / 8$ cooling time of $25 \mathrm{~min}$ considered as proper cooling time for both herbs. The present study aims to test and evaluate the changes in quality of three different herbs of spearmint, sage and thyme hydro cooled at $5{ }^{\circ} \mathrm{C}$ and stored at different levels of storing temperature $\left(1,3\right.$ and $\left.5{ }^{\circ} \mathrm{C}\right)$, constant relative humidity of $98 \%$. The evaluation basis included fresh weight loss, chlorophyll $a$ and $b$, volatile oil percentage and its components and the safe storage period of each studied herb.

\section{MATERIALS AND METHODS}

\section{A) Materials:}

The experimental work was conducted at the Department of Processing and Handling of Agricultural Crops, Agricultural Engineering Research Institute and the Medicinal and Aromatic Plants Research Department, Horticulture Research Institute, during season of 2013. The samples of herbs plants were obtained from the experimental farm of Horticulture Research Institute to investigate the effect of precooling process on safe storage period, fresh weight loss, respiration rate and volatile oil percentage and its components of spearmint, sage and thyme as non chilling sensitive herbs. The collected plants were hydro-cooled at $5{ }^{\circ} \mathrm{C}$ and stored under three levels of storage temperatures $\left(1,3\right.$ and $\left.5^{\circ} \mathrm{C}\right)$. The properties of each plant was analyzed at the laboratory of the Medicinal and Aromatic Plants Department, Horticultural Research Institute.

\section{1- Herbs used in the present investigation:}

Arial stem terminal parts of spearmint, sage and thyme plants $(12-15 \mathrm{~cm}$ in length) were used (approximately $50 \mathrm{~g}$ for package at foam). The cutting of these parts was done in July 2013.

\section{2- Data Recorded:}

The following data were recorded

\section{Safe storage period (days):}

The parameters in which the fresh herb of the pre-cooled and non-pre cooled remained in good quality till the beginning of deterioration was measured. This parameters included:

\section{a- Fresh weight loss (g):}

The difference between weights of sample before and after storage was determined by digital balance with accuracy of $0.01 \mathrm{~g}$. 


\section{b- Photosynthetic pigments determination of the fresh leaves:}

Chlorophyll $a$ and $b$ contents were determined in fresh leaves $(\mathrm{mg} / \mathrm{g})$ according to the procedure of Saric et al. (1967).

\section{c- Volatile oil and its components:}

The percentages of volatile oil were determined in the fresh herbs using $100 \mathrm{~g}$ samples for each plant. Distillation of the volatile oil was carried out as described in the British Pharmcopoeia (1963).

\section{3- Plants temperature during the hydro-cooling process:}

The digital universal temperature meter with copper-constantan thermocouple was used for measuring the temperature change of each plant during the pre-cooling process.

\section{4- Respiration rate $\left(\mathrm{Wt}^{-1}\right)$ :}

One hundred herbs were placed in a dissector and connected to a tube contains $25 \mathrm{ml}$ of $1.0 \mathrm{~N} \mathrm{KOH}$. Air free from $\mathrm{CO}_{2}$ was drown into the dessicator through, the $\mathrm{KOH}$ for one hour, then $\mathrm{KOH}$ was titrated with $1.0 \mathrm{~N} \mathrm{HC1}$ using thymol blue indicator and $\mathrm{CO}_{2}$ production was calculated as $\mathrm{mg} \mathrm{CO}_{2} \mathrm{~kg}^{-1} \mathrm{~h}^{-1}$. Each value was converted into $\mathrm{Wt}^{-1}\left(1 \mathrm{CO}_{2} \mathrm{~kg}^{-1} \mathrm{~h}^{-1}=3.0287 \mathrm{Wt}^{-1}\right)$

\section{B) Methods:}

\section{Experimental treatments and test producers:}

The freshly harvested herbs were divided into two parts one of them was kept without pre-cooling (C1) and the other one was subjected to Hydro-cooling $\left(\mathrm{C}_{2}\right)$ at 5 $\pm 1.0{ }^{\circ} \mathrm{C}$ before storing at storage temperature of 1,3 and $5{ }^{\circ} \mathrm{C}$ and $98 \%$ relative humidity (R.H.). The storage process was done in three different refrigerators at the Horticulture Research Institute, A.R.C., Dokki, Giza, Egypt.

\section{Analysis of cooling process:}

The rate of cooling depends upon the specific characteristics of a product such as: density, thermal capacity and conductivity the temperature difference between the product and its surrounding also influences the cooling rate. As the product cooling down, the temperature difference changes and therefore the cooling rate usually become time dependence. An object placed in surroundings at a constant lower temperature, with negligible temperature gradient within the object and constant thermal properties will follow the Neutrons' low for conduction cooling: $\mathrm{T}=\mathrm{tr}+(\mathrm{ti}-\mathrm{tr}) \mathrm{e}^{-\mathrm{c} \theta}$

Where: $\mathrm{T}=$ product temperature at any given time ${ }^{\circ} \mathrm{C}$, $\mathrm{ti}=$ initial product temperature ${ }^{\circ} \mathrm{C}$., $\operatorname{tr}=$ water temperature ${ }^{\circ} \mathrm{C}$., $\mathrm{e}=$ constant $2.718828 ., \mathrm{C}=$ specific cooling coefficient $\left(\mathrm{s}^{-1}\right), \theta=$ time which one wants to find $t(\mathrm{~s})$,, It is obvious from equation (1) that, the time needed to cool down the product to its surrounding temperature is going to be infinitely long. A term called the half-cooling time is used instead as it gives a practical meaning for the characterized cooling rate. Half cooling time often denoted by the letter $Z$ is defined as the time needed to reduce by half the 
temperature difference between the initial product temperature and the cooling medium temperature (Thompson et al., 1998). In the second half of the cooling time the temperature difference is reduced again by a half. After three half cooling times are elapsed the difference becomes only $1 / 8$ of the initial difference and so on. At the $7 / 8$ cooling time, the cooling rate become very slow and the cooling process can be stopped to save the cooling energy and the cost of the process at the present study $1 / 2$, and $7 / 8$ cooling time were calculated for the three studied herbs plants.

\section{Data analysis:}

Analysis of Variance (ANOVA) was proceeded according to Snedecor and Cochran, (1990) at probability of $5 \%$.

\section{RESULTS AND DISCUSSION}

\section{1- Hydro-cooling process}

Fig. (1), illustrates the change in spearmint, sage and thyme herbs temperature as related to cooling time. As shown in the figure the cooling rate of herbs increased during the early stage of pre-cooling process and starts to decline with time. Also, the cooling rate was depended upon the specific characteristics of each herb. Cooling rate is usually described in term of half-cooling, 3/4 cooling time or $7 / 8$ cooling time. These values remain constant for a given system. Under the testing condition of this study, and as shown in Table (1) for the Spearmint the half-cooling time, 3/4 cooling time and the $7 / 8$ cooling time were $24.5,19.75$ and 17.38 mins respectively. While, the corresponding values for the Sage herb were 25, 20 and 17.5 min., respectively, and they were $25.5,20.25$ and $17.63 \mathrm{~min}$. For the Thyme herb. This means that, at cooling temperature of $5{ }^{\circ} \mathrm{C}$, the cooling rate and the corresponding $1 / 2,3 / 4$ and $7 / 8$ cooling times of the three studied herbs were very close. This means that, at the average $7 / 8$ cooling time of ( $17.5 \mathrm{~min}$.), the pre-cooling process should be stopped to save the cooling energy and the cost of cooling process as mentioned by (Thompson et al., 1998).

Table 1. Cooling time (min.) for spearmint, sage and thyme during the hydro-cooling process.

\begin{tabular}{|c|c|c|c|}
\hline \multirow{2}{*}{ Aromatic plants } & \multicolumn{3}{|c|}{ Cooling time, min. } \\
\cline { 2 - 4 } & $1 / 2$ cooling time & $3 / 4$ cooling time & $7 / 8$ cooling time \\
\hline Spearmint & 24.50 & 19.75 & 17.38 \\
\hline Sage & 25.00 & 20.00 & 17.50 \\
\hline Thyme & 25.50 & 20.25 & 17.63 \\
\hline
\end{tabular}



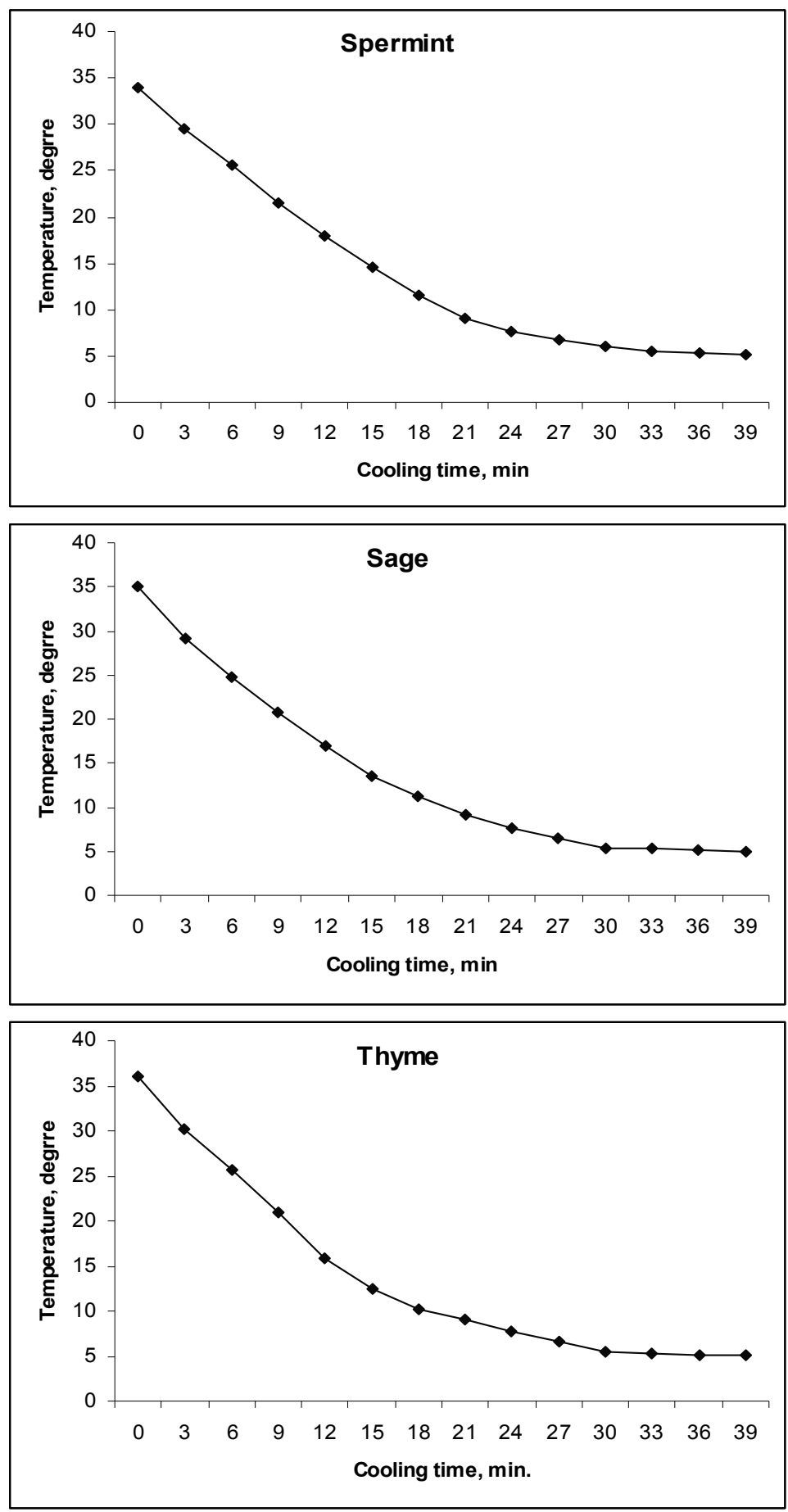

Fig. 1. Reduction of spearmint, sage and thyme temperatures as related to cooling time.

\section{2- Weight loss as affected by the pre-cooling process and storage temperature:}

Data in Table (2) show the effect of pre-cooling process and the cold storage temperature on fresh weight loss $(\mathrm{g})$ of Spearmint, Sage and Thyme. The results show that, the fresh weight loss was affected by the pre-cooling process and storage temperatures. It could be noted that the non pre-cooled treatments gave high fresh 
weight loss when compared with the pre-cooled treatments for Spearmint, Sage and Thyme at all levels of storage temperature. Also the fresh weight loss increased by increasing the storage temperatures from 1 to $5{ }^{\circ} \mathrm{C}$.

The maximum fresh weight losses of $15.22,5.60$ and $3.71 \mathrm{~g} / 100 \mathrm{~g}$ were obtained for Spearmint, Sage and Thyme samples stored mentioned, respectively without precooling at temperature of $5{ }^{\circ} \mathrm{C}$. While corresponting the minimum fresh weight losses of $11.21,3.47$ and $1.55 \mathrm{~g} / 100 \mathrm{~g}$ were obtained for the pre-cooled samples stored at temperature of $1{ }^{\circ} \mathrm{C}$.

Table 2. Effect of pre-cooling process and storage temperatures on fresh weight loss $\mathrm{g} / 100 \mathrm{~g}$ fresh herbs.

\begin{tabular}{|c|c|c|c|c|c|c|}
\hline \multirow{2}{*}{ Plants } & \multicolumn{5}{|c|}{ Fresh weight loss (g)/ 100 g fresh herbs } \\
\cline { 2 - 7 } & \multicolumn{2}{|c|}{$\mathrm{C} 1$} & \multicolumn{3}{c|}{$\mathrm{C} 2$} \\
\cline { 2 - 7 } & \multicolumn{2}{|c|}{ Storage temperatures, ${ }^{\circ} \mathrm{C}$} & \multicolumn{2}{c|}{ Storage temperatures, ${ }^{\circ} \mathrm{C}$} \\
\cline { 2 - 7 } & 1 & 3 & 5 & 1 & 3 & 5 \\
\hline Spearmint & 14.02 & 14.71 & 15.22 & 11.21 & 11.44 & 11.81 \\
\hline \multirow{2}{*}{ Sage } & 5.41 & 5.25 & 5.60 & 3.47 & 3.53 & 3.60 \\
\hline \multirow{2}{*}{ Thyme } & 3.11 & 3.55 & 3.71 & 1.55 & 1.90 & 2.35 \\
\hline
\end{tabular}

The weight loss of stored herb may be due to decreasing in degradable tissues and the higher respiration rate of the herbs stored without pre-cooling.

\section{3- Chlorophyll (a and $b$ ) as affected by pre-cooling process and storage temperature.}

As shown in Table (3) for both pre-cooled and non-pre-cooled Spearmint, Sage and Thyme plants, the chlorophyll content decreased with the increasing of cooled storage temperature. However, the decrease of chlorophyll, $(a, b)$ with the increasing of storage temperature was obvious for the non-pre-cooled samples in comparison with the pre-cooled samples. These results may be returned to, the herbs subjected to pre-cooling treatment preserved greater amounts of chlorophyll with less colour change than those of non pre-cooled herbs. 
Table 3. Effect of pre-cooling and storage temperatures on chlorophyll ( $a$ and $b$ ) contents $(\mathrm{mg} / \mathrm{g})$.

\begin{tabular}{|c|c|c|c|c|c|c|c|}
\hline \multirow{2}{*}{ Plants } & \multirow{2}{*}{$\begin{array}{c}\text { Chloro-phyll, } \\
\text { (mg/g) }\end{array}$} & \multicolumn{3}{|c|}{ Treatments } \\
\cline { 3 - 8 } & & \multicolumn{3}{|c|}{ C1 } & \multicolumn{3}{c|}{ C2 } \\
\cline { 3 - 8 } & & 1 & 3 & 5 & 1 & 3 & 5 \\
\hline \multirow{2}{*}{ Spearmint } & (a) & 0.56 & 0.52 & 0.46 & 0.63 & 0.63 & 0.59 \\
& (b) & 0.32 & 0.31 & 0.29 & 0.32 & 032 & 0.31 \\
\hline \multirow{2}{*}{ Sage } & (a) & 1.29 & 1.27 & 1.21 & 1.59 & 1.55 & 1.49 \\
& (b) & 0.69 & 0.55 & 0.51 & 0.87 & 0.84 & 0.78 \\
\hline \multirow{2}{*}{ Thyme } & (a) & 0.72 & 0.68 & 0.65 & 0.90 & 0.88 & 0.82 \\
& (b) & 0.28 & 0.26 & 0.24 & 0.36 & 0.35 & 0.32 \\
\hline
\end{tabular}

\section{4- Volatile oil (\%) as affected by the pre-cooling process and storage temperature.}

Data in Table (4) show the effect of pre-cooling and storage temperatures on volatile oil percentage of Spearmint, Sage and Thyme plants. As shown in the Table, the extracted oil percentage was higher for the pre-cooled samples in comparison with the non-cooled samples. Also the volatile oil percentage slightly decreased by increasing the storage temperatures from 1 to $5{ }^{\circ} \mathrm{C}$. For Spearmint, Sage and Thyme, the maximum volatile oil percentages were $0.275,0.279$ and $0.581 \%$, respectively for the pre-cooled herbs stored at $1{ }^{\circ} \mathrm{C}$, while the minimum volatile oil percentages were $0.196,0.227$ and 0.394 for the non pre-cooled herb stored at $5{ }^{\circ} \mathrm{C}$.

Table 4. Effect of pre-cooling and storage temp. on volatile oil percentage.

\begin{tabular}{|c|c|c|c|c|c|c|}
\hline \multirow{2}{*}{ Plants } & \multicolumn{5}{|c|}{ Volatile oil \% } \\
\cline { 2 - 7 } & \multicolumn{3}{|c|}{ C1 } & \multicolumn{3}{c|}{ C2 } \\
\cline { 2 - 7 } & \multicolumn{2}{|c|}{ Storage temperatures, ${ }^{\circ} \mathrm{C}$} & \multicolumn{3}{c|}{ Storage temperatures, ${ }^{\circ} \mathrm{C}$} \\
\cline { 2 - 7 } & 1 & 3 & 5 & 1 & 3 & 5 \\
\hline Spearmint & 0.212 & 0.205 & 0.196 & 0.275 & 0.270 & 0.269 \\
\hline Sage & 0.297 & 0.285 & 0.227 & 0.279 & 0.256 & 0.245 \\
\hline Thyme & 0.491 & 0.436 & 0.394 & 0581 & 0.532 & 0.508 \\
\hline
\end{tabular}




\section{5- Effect of pre-cooling process on volatile oil components at storage temperature of $1^{\circ} \mathrm{C}$.}

Data in Tables $(5,6$ and 7) indicate that: For Spearmint Sage and Thyme herbs the main components of the extracted oil were Carvone, Thujone and Thymol, respectively. However, the maximum percentages of Carvone, Thujone and Thymol were $60.99,46.63$ and $40.44 \%$ and the minimum linalool content of 59.34, 44.91and $40.31 \%$ obtained from the pre-cooled herbs stored at $1{ }^{\circ} \mathrm{C}$ storage temperature.

Table 5. Effect of pre-cooling on spearmint volatile oil components (\%) at storage temperature of $1{ }^{\circ} \mathrm{C}$.

\begin{tabular}{|c|c|c|}
\hline \multirow{2}{*}{ Components } & \multicolumn{2}{|c|}{ Spearmint } \\
\cline { 2 - 3 } & C1 & C2 \\
\hline a-pinene & 1.54 & 1.43 \\
\hline$\beta$-pinene & 3.94 & 4.01 \\
\hline Limonene & 16.17 & 16.65 \\
\hline 1,8 cineole & 0.74 & 1.02 \\
\hline y-terpinene & 1.05 & 1.09 \\
\hline Linalool & 4.93 & 5.05 \\
\hline Carvone & 59.34 & 60.99 \\
\hline a -terpineol & 2.29 & 2.41 \\
\hline B-carophyllene & 3.36 & 3.35 \\
\hline Eugenol & 3.24 & 1.61 \\
\hline Unidentified & 3.40 & 2.39 \\
\hline
\end{tabular}

Table 6. Effect of pre-cooling on sage volatile oil components (\%) at storage temperature of $1^{\circ} \mathrm{C}$.

\begin{tabular}{|c|c|c|}
\hline \multirow{2}{*}{ Components } & \multicolumn{2}{|c|}{ Sage } \\
\cline { 2 - 3 } & \multicolumn{2}{|c|}{ C1 } \\
\hline a - pinene & 4.88 & 5.24 \\
\hline Camphene & 4.10 & 4.17 \\
\hline$\beta$-pinene & 11.85 & 10.50 \\
\hline Thujone & 44.91 & 46.63 \\
\hline Cineole & 0.13 & 0.78 \\
\hline Trpinene & 1.17 & 0.93 \\
\hline Linalool & 6.20 & 7.11 \\
\hline Methyl chavicol & 3.40 & 3.38 \\
\hline Linalyl acetate & 1.85 & 1.26 \\
\hline Camphor & 2.96 & 3.01 \\
\hline Borneol & 3.20 & 2.23 \\
\hline Eugenol & 1.89 & 1.79 \\
\hline Unidentified & 13.46 & 12.96 \\
\hline
\end{tabular}


Table 7. Effect of pre-cooling on thyme volatile oil components (\%) at storage temperature of $1{ }^{\circ} \mathrm{C}$.

\begin{tabular}{|c|c|c|}
\hline \multirow{2}{*}{ Components } & \multicolumn{2}{|c|}{ Thyme } \\
\cline { 2 - 3 } & $\mathrm{C} 1$ & $\mathrm{C} 2$ \\
\hline $\mathrm{a}-$ pinen & 0.89 & 0.90 \\
\hline P-.cymene & 20.59 & 20.66 \\
\hline Carvacrol & 18.08 & 18.14 \\
\hline 1,8 cineol & 2.01 & 2.01 \\
\hline Thymol & 40.31 & 40.44 \\
\hline Unknown & 18.12 & 17.85 \\
\hline
\end{tabular}

\section{6- Respiration rate as affected by pre-cooling and storage temperature.}

As shown in Table (8) for all studied plants the respiration rate of both pre-cooled and non pre-cooled samples decreased with the decrease of storage temperature. While it was relatively higher for the non pre-cooled samples in comparison with the non pre-cooled samles at all levels of storage temperature. Also the spearmint plants recorded the highest respiration rate followed by sage and thyme plants respectively.

Table 8. Effect of pre-cooling and storage temperatures on respiration rate of spearmint, sage and thyme.

\begin{tabular}{|c|c|c|c|c|c|c|}
\hline \multirow{4}{*}{ Plants } & \multicolumn{6}{|c|}{ Respiration rate } \\
\hline & \multicolumn{3}{|c|}{$\mathrm{C} 1$} & \multicolumn{3}{|c|}{$\mathrm{C} 2$} \\
\hline & \multicolumn{3}{|c|}{ Storage temperatures, ${ }^{\circ} \mathrm{C}$} & \multicolumn{3}{|c|}{ Storage temperatures, ${ }^{\circ} \mathrm{C}$} \\
\hline & 1 & 3 & 5 & 1 & 3 & 5 \\
\hline Spearmint & 261.43 & 264.13 & 267.22 & 248.51 & 240.11 & 243.89 \\
\hline Sage & 216.32 & 219.22 & 222.34 & 201.91 & 204.51 & 206.16 \\
\hline Thyme & 196.32 & 203.22 & 218.34 & 182.91 & 189.51 & 192.16 \\
\hline
\end{tabular}

In general the pre-cooling process is an efficient method to reduce the metabolic activity of a plant, as the rate of biochemical reactions such as respiration rate may decreased and lead to a longer storage period.

\section{7- Safe storage period as affected by pre-cooling and storage temperature.}

Based on acceptable limit of changes occurred on the volatile oil component of the stored herbs, the safe storage period of the pre-cooled and non-cooled samples were determined and tabulated in Table (9). 
Table 9. Effect of pre-cooling and storage temperatures on the storage period (days).

\begin{tabular}{|c|c|c|c|c|c|c|}
\hline \multirow{3}{*}{ Plants } & \multicolumn{5}{|c|}{ C1 } & \multicolumn{3}{c|}{ C2 } \\
\cline { 2 - 7 } & \multicolumn{3}{|c|}{ Storage temperatures, ${ }^{\circ} \mathrm{C}$} & \multicolumn{3}{c|}{ Storage temperatures, ${ }^{\circ} \mathrm{C}$} \\
\cline { 2 - 7 } & 1 & 3 & 5 & 1 & 3 & 5 \\
\cline { 2 - 7 } & 14 & 11 & 9 & 20 & 17 & 14 \\
\hline Spearmint & 17 & 15 & 12 & 25 & 23 & 20 \\
\hline Sage & 20 & 17 & 15 & 27 & 23 & 20 \\
\hline Thyme & &
\end{tabular}

As shown in the Table (9). longer safe storage period for the pre-cooled plants were observed in comparison with non pre-cooled samples While the storage period decreased by increasing the storage temperature from 1 to $5{ }^{\circ} \mathrm{C}$ for both pre-cooled and non pre-cooled samples. The assessment of safe storage period shown in the Table (9) was obtained according to the significant difference between the quality of the fresh samples and the treated samples in terms of fresh weight loss. percentage of volatile oil and the contents of chlorophyll A and B mg/g The date of occurring this significant difference is considered as the maximum safe storage period for the stored samples of each studied herb. Tables (10 and 11) show samples of the conducted analysis.

Table 10. Analysis of Variance for fresh weight loss of different studied plants.

\begin{tabular}{|c|c|c|c|c|c|c|c|c|}
\hline \multirow[b]{2}{*}{ Plant } & \multirow[b]{2}{*}{ Treatment } & \multirow{2}{*}{$\begin{array}{c}\text { Storag } \\
\text { e } \\
\text { temp. }\end{array}$} & \multicolumn{6}{|c|}{ Storage time / days } \\
\hline & & & $\begin{array}{c}\text { contro } \\
1\end{array}$ & 5 & 10 & 15 & 20 & 25 \\
\hline \multirow{6}{*}{ Spearmint } & \multirow[t]{3}{*}{$\begin{array}{l}\text { Without } \\
\text { pre-cooling }\end{array}$} & $1{ }^{\circ} \mathrm{C}$ & $8.55 \mathrm{~b}$ & $8.91 \mathrm{~b}$ & $8.95 \mathrm{~b}$ & $14.14 \mathrm{a}$ & $\begin{array}{l}15.67 \\
\mathrm{a}\end{array}$ & $16.29 \mathrm{a}$ \\
\hline & & $3{ }^{\circ} \mathrm{C}$ & $8.55 \mathrm{~b}$ & $8.91 \mathrm{~b}$ & $8.95 \mathrm{~b}$ & $15.14 \mathrm{a}$ & $\begin{array}{l}16.67 \\
a\end{array}$ & $17.29 \mathrm{a}$ \\
\hline & & $5^{\circ} \mathrm{C}$ & $8.55 \mathrm{~b}$ & $8.91 \mathrm{~b}$ & $16.62 \mathrm{a}$ & $17.81 \mathrm{a}$ & $\begin{array}{l}18.00 \\
a\end{array}$ & $18.29 \mathrm{a}$ \\
\hline & \multirow[t]{3}{*}{$\begin{array}{l}\text { With } \\
\text { pre-cooling }\end{array}$} & $1^{\circ} \mathrm{C}$ & $6.91 \mathrm{~b}$ & $7.54 \mathrm{~b}$ & $9.51 \mathrm{~b}$ & $9.99 \mathrm{~b}$ & $\begin{array}{l}10.03 \\
\mathrm{~b}\end{array}$ & $15.57 \mathrm{a}$ \\
\hline & & $3{ }^{\circ} \mathrm{C}$ & $6.91 \mathrm{~b}$ & $7.54 \mathrm{~b}$ & $9.51 \mathrm{~b}$ & $9.99 \mathrm{~b}$ & $\begin{array}{l}15.03 \\
a\end{array}$ & $15.57 \mathrm{a}$ \\
\hline & & $5^{\circ} \mathrm{C}$ & $6.91 \mathrm{~b}$ & $7.54 \mathrm{~b}$ & $9.51 \mathrm{~b}$ & $13.66 \mathrm{a}$ & $\begin{array}{l}15.03 \\
a\end{array}$ & $15.57 \mathrm{a}$ \\
\hline \multirow{6}{*}{ Sage } & \multirow[t]{3}{*}{$\begin{array}{l}\text { Without } \\
\text { pre-cooling }\end{array}$} & $1{ }^{\circ} \mathrm{C}$ & $9.00 \mathrm{~b}$ & $9.13 b$ & $\begin{array}{l}10.16 \\
b\end{array}$ & $11.37 \mathrm{~b}$ & $\begin{array}{l}15.10 \\
\mathrm{a} \\
\end{array}$ & $15.79 \mathrm{a}$ \\
\hline & & $3^{\circ} \mathrm{C}$ & $9.00 \mathrm{~b}$ & $9.13 \mathrm{~b}$ & $\begin{array}{l}10.16 \\
\mathrm{~b} \\
\end{array}$ & $11.37 \mathrm{~b}$ & $\begin{array}{l}16.10 \\
a\end{array}$ & $16.79 \mathrm{a}$ \\
\hline & & $5^{\circ} \mathrm{C}$ & $9.00 \mathrm{~b}$ & $9.13 \mathrm{~b}$ & $\begin{array}{l}10.16 \\
\mathrm{~b} \\
\end{array}$ & $14.37 \mathrm{a}$ & $\begin{array}{l}16.77 \\
a \\
\end{array}$ & $17.46 \mathrm{a}$ \\
\hline & \multirow{3}{*}{$\begin{array}{l}\text { With } \\
\text { pre-cooling }\end{array}$} & $1{ }^{\circ} \mathrm{C}$ & $7.98 \mathrm{a}$ & $8.00 \mathrm{a}$ & $8.29 a$ & $9.10 a$ & $9.92 \mathrm{a}$ & $10.04 \mathrm{a}$ \\
\hline & & $3{ }^{\circ} \mathrm{C}$ & $\begin{array}{l}7.98 \\
b\end{array}$ & $\begin{array}{l}8.00 \\
b\end{array}$ & $8.29 \mathrm{~b}$ & $9.10 \mathrm{~b}$ & $9.92 \mathrm{~b}$ & $14.04 \mathrm{a}$ \\
\hline & & $5^{\circ} \mathrm{C}$ & $\begin{array}{l}7.98 \\
b \\
\end{array}$ & $\begin{array}{l}8.00 \\
b \\
\end{array}$ & $8.29 \mathrm{~b}$ & $9.10 \mathrm{~b}$ & $9.92 \mathrm{~b}$ & $15.15 a$ \\
\hline \multirow{6}{*}{ Thyme } & \multirow[t]{3}{*}{$\begin{array}{l}\text { Without } \\
\text { pre-cooling }\end{array}$} & $1{ }^{\circ} \mathrm{C}$ & $9.69 \mathrm{~b}$ & $9.83 \mathrm{~b}$ & $\begin{array}{l}10.30 \\
b \\
\end{array}$ & $11.45 \mathrm{~b}$ & $\begin{array}{l}11.63 \\
\mathrm{~b}\end{array}$ & $15.02 \mathrm{a}$ \\
\hline & & $3^{\circ} \mathrm{C}$ & $9.69 \mathrm{~b}$ & $9.83 \mathrm{~b}$ & $\begin{array}{l}10.30 \\
\mathrm{~b} \\
\end{array}$ & $11.45 \mathrm{~b}$ & $\begin{array}{l}14.97 \\
a \\
\end{array}$ & $15.35 \mathrm{a}$ \\
\hline & & $5^{\circ} \mathrm{C}$ & $9.69 \mathrm{~b}$ & $9.83 \mathrm{~b}$ & $\begin{array}{l}10.30 \\
b\end{array}$ & $11.45 \mathrm{~b}$ & $\begin{array}{l}15.68 \\
a\end{array}$ & $15.96 \mathrm{a}$ \\
\hline & \multirow[t]{3}{*}{$\begin{array}{l}\text { With } \\
\text { pre-cooling }\end{array}$} & $1^{\circ} \mathrm{C}$ & $6.94 a$ & $7.04 a$ & $7.39 \mathrm{a}$ & $7.66 \mathrm{a}$ & $8.15 \mathrm{a}$ & $\begin{array}{l}8.28 \\
a\end{array}$ \\
\hline & & $3{ }^{\circ} \mathrm{C}$ & $6.94 \mathrm{a}$ & $7.04 \mathrm{a}$ & 7.39 a & $7.66 \mathrm{a}$ & $8.15 \mathrm{a}$ & $12.28 \mathrm{~b}$ \\
\hline & & $5^{\circ} \mathrm{C}$ & $6.94 \mathrm{a}$ & $7.04 \mathrm{a}$ & $7.39 \mathrm{a}$ & $7.66 \mathrm{a}$ & $8.15 \mathrm{a}$ & $13.28 \mathrm{~b}$ \\
\hline
\end{tabular}

Note. Similar characters denote no significant difference. 
Table 11. Analysis of Variance for the volatile oil content of different studied plants.

\begin{tabular}{|c|c|c|c|c|c|c|c|c|}
\hline \multirow[t]{2}{*}{ Plant } & \multirow[t]{2}{*}{ Treatment } & \multirow{2}{*}{$\begin{array}{l}\text { Storage } \\
\text { temp. }\end{array}$} & \multicolumn{6}{|c|}{ Storage time / days } \\
\hline & & & control & 5 & 10 & 15 & 20 & 25 \\
\hline \multirow{6}{*}{ Spearmint } & \multirow{3}{*}{$\begin{array}{l}\text { Without } \\
\text { pre-cooling }\end{array}$} & $1^{\circ} \mathrm{C}$ & $0.56 a$ & $0.55 a$ & $0.55 a$ & $0.43 \mathrm{~b}$ & $0.41 \mathrm{~b}$ & $0.41 b$ \\
\hline & & $3{ }^{\circ} \mathrm{C}$ & $0.56 a$ & $0.55 \mathrm{a}$ & $0.55 a$ & $0.42 \mathrm{~b}$ & $0.41 \mathrm{~b}$ & $0.40 \mathrm{~b}$ \\
\hline & & $5^{\circ} \mathrm{C}$ & $0.56 a$ & $0.55 \mathrm{a}$ & $0.43 b$ & $0.42 b$ & $0.40 \mathrm{~b}$ & $0.39 \mathrm{~b}$ \\
\hline & \multirow{3}{*}{$\begin{array}{c}\text { With } \\
\text { pre-cooling }\end{array}$} & $1^{\circ} \mathrm{C}$ & $0.65 a$ & $0.65 \mathrm{a}$ & $0.64 a$ & $0.64 a$ & $0.63 a$ & $0.53 b$ \\
\hline & & $3^{\circ} \mathrm{C}$ & $0.65 a$ & $0.65 \mathrm{a}$ & $0.64 a$ & $0.64 a$ & $0.52 b$ & $0.51 b$ \\
\hline & & $5^{\circ} \mathrm{C}$ & $0.65 a$ & $0.65 \mathrm{a}$ & $0.64 \mathrm{a}$ & $0.53 \mathrm{~b}$ & $0.51 b$ & $0.49 \mathrm{~b}$ \\
\hline \multirow{6}{*}{ Sage } & \multirow{3}{*}{$\begin{array}{l}\text { Without } \\
\text { pre-cooling }\end{array}$} & $1^{\circ} \mathrm{C}$ & $0.85 a$ & $0.83 a$ & $0.83 a$ & $0.80 \mathrm{a}$ & $0.61 \mathrm{~b}$ & $0.57 b$ \\
\hline & & $3^{\circ} \mathrm{C}$ & $0.85 a$ & $0.83 a$ & $0.83 a$ & $0.80 a$ & $0.59 \mathrm{~b}$ & $0.56 \mathrm{~b}$ \\
\hline & & $5^{\circ} \mathrm{C}$ & $0.85 a$ & $0.83 a$ & $0.83 a$ & $0.59 \mathrm{~b}$ & $0.57 \mathrm{~b}$ & $0.56 \mathrm{~b}$ \\
\hline & \multirow{3}{*}{$\begin{array}{c}\text { With } \\
\text { pre-cooling }\end{array}$} & $1^{\circ} \mathrm{C}$ & $0.88 a$ & $0.87 a$ & $0.87 a$ & $0.84 a$ & $0.82 \mathrm{a}$ & $0.79 \mathrm{a}$ \\
\hline & & $3^{\circ} \mathrm{C}$ & $0.88 a$ & $0.87 a$ & $0.87 a$ & $0.84 a$ & $0.81 \mathrm{a}$ & $0.69 \mathrm{~b}$ \\
\hline & & $5^{\circ} \mathrm{C}$ & $0.88 a$ & $0.87 a$ & $0.87 \mathrm{a}$ & $0.84 a$ & $0.79 a$ & $0.62 b$ \\
\hline \multirow[b]{6}{*}{ Thyme } & \multirow{3}{*}{$\begin{array}{c}\text { Without } \\
\text { pre-cooling }\end{array}$} & $1{ }^{\circ} \mathrm{C}$ & $1.02 \mathrm{a}$ & $1.01 \mathrm{a}$ & $1.00 \mathrm{a}$ & $0.98 a$ & $0.98 \mathrm{a}$ & $0.48 b$ \\
\hline & & $3^{\circ} \mathrm{C}$ & $1.02 \mathrm{a}$ & $1.01 \mathrm{a}$ & $1.00 \mathrm{a}$ & $0.98 a$ & $0.50 \mathrm{~b}$ & $0.48 b$ \\
\hline & & $5^{\circ} \mathrm{C}$ & $1.02 \mathrm{a}$ & $1.01 \mathrm{a}$ & $1.00 \mathrm{a}$ & 0.98 a & $0.48 \mathrm{~b}$ & $0.48 b$ \\
\hline & \multirow{3}{*}{$\begin{array}{c}\text { With } \\
\text { pre-cooling }\end{array}$} & $1^{\circ} \mathrm{C}$ & $1.04 \mathrm{a}$ & $1.03 \mathrm{a}$ & $1.00 \mathrm{a}$ & 0.99 a & $0.97 a$ & $0.97 \mathrm{a}$ \\
\hline & & $3^{\circ} \mathrm{C}$ & $1.04 \mathrm{a}$ & $1.03 \mathrm{a}$ & $1.00 \mathrm{a}$ & 0.99 a & 0.97 a & $0.51 \mathrm{~b}$ \\
\hline & & $5^{\circ} \mathrm{C}$ & $1.04 \mathrm{a}$ & $1.03 \mathrm{a}$ & $1.00 \mathrm{a}$ & $0.99 a$ & 0.97 a & $0.50 \mathrm{~b}$ \\
\hline
\end{tabular}

Note. Similar characters denote no significant difference.

\section{CONCLUSION}

\section{The obtained results could be summarized as follows:}

1- The average $7 / 8$ cooling time of 17.5 min. considered as proper cooling time for the studied herbs.

2-The pre-cooling process increased the storage period for Spearmint, Sage and Thyme herbs. Also the safe storage period decreased by increasing the storage temperatures from 1 to $5^{\circ} \mathrm{C}$.

3-The non pre-cooled samples gave higher fresh weight ( $\mathrm{g}$ ) loss when compared with the pre-cooled samples for Spearmint, Sage and Thyme herbs. Also the fresh weight loss increased by increasing the storage temperatures from 1 to $5 \mathrm{oC}$.

4-Volatile oil percentage and respiration rate were affected by the pre-cooling process for Spearmint, Sage and Thyme herbs.

5-To obtain the longest safe storage period for fresh consumption or marketing after harvesting of Spearmint, Sage and Thyme, herbs, they should be pre-cooled at 5 ${ }^{\circ} \mathrm{C}$ and stored at $1{ }^{\circ} \mathrm{C}$ and $98 \%$ R.H. 


\section{REFERENCES}

1. Alvares, V. S., F. L. Finger, R. C. Santos, J. R. Negreiros, and V. W. D. Casali. 2007. Effect of pre-cooling on the pot-harvest of parsley leaves. J. Food, Agric. And Environ. (JFAE), Helsinki, Finland, 5 (2): 31-34.

2. British Pharmcopoeia. 1963. Determination of volatile oil in drugs. The Pharmaceutical Press, London.

3. Cantwell, M. I. and M. S. Reid. 1993. Post-harvest physiology and handling of fresh culinary herbs. J. Herbs, Spices, Med. PI., 1 :93-127.

4. Ferreira, M. D, J. K. Brecht, S. A. Sargent and J. J. Aracena. 1994. Physiological responses of strawberry to film wrapping and pre-cooling methods. Proc. Fla. State Hort. Soc. 107: 265-269.

5. Gillies, S. L. and P. M. Tovionen. 1995. Cooling method influences the postharvest quality of broccoli. Hort. Sci., 30(2): 313-315.

6. Gomez, E., J. Labarca, M. Guerroro, M. Marin and B. Bracho 1999. Post-harvest performance of coriander (Coriandrum sativum L.) under refrigeration. Revista de la Facultad de Agronomis, Univ. de Lzulia 16 (Suppl) 146-150 (Hort. Abst., 70 (4): 3514).

7. Reina, L. D, H. P. Fleming, and E. G. Humphries. 1995. Microbial control of cucumber hydro-cooling water with chlorine dioxide J. Food Protect., 58(5): 451456.

8. Saric, M., R. Kastrori, R. Couria, T. Cupina and I. Gerie. 1967. Chlorophyll determination. Univ. Unoven sadu Parktikum is Fiziologize Bilijaka, Beagard, Hauncan, Anjiga, P. 215.

9. Snedecor, G.w. and Cochran, W.G. 1990. Statistical Methods, 9th ed. Iowa State Unive. Press, Iowa, USA.

10. 10-Thompson J. F., Gordon M.F., Rumsey T. P., Kasmive R. F. and Grisosto C. H. 1998. Commercial cooling of fruits, vegetables and flowers. Univ. of California Div. of Agric., and Natural Resources. Publication No. 21567. P. 10.

11. Yamauchi, N. and A. E. Watada. 1991. Regulated chlorophyll gegradation in spinach leaves during storage. J. Amer. Soc. Hort. Sci., 116: 58-62.

12. Ebaid, M.T., M. M. Abd El-rahman and A. A. Ahmed. 2009. Effect of pre-cooling process on the cold storage and quality of some aromatic plants. J. Agric.sci. Mansoura Univ., 34(7):8559-8571. 


\section{تأثير التبريد المبدئى والتخزين المبرد على فترة التخزين \\ الآمن لبعض النباتات الطبية و العطرية \\ جمال كمال عرفة' و احم عبدالعزيز احمد دويدار؟

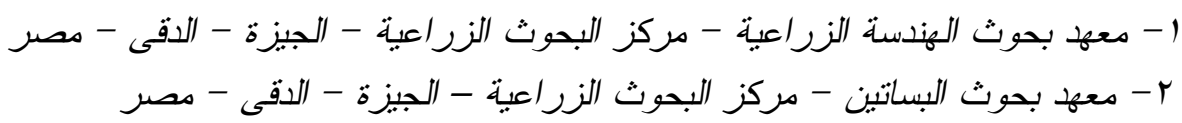

يتتاول هذا البحث دراسة تاثير التبريد المبدئى والتخزين المبرد على طول مدة التخزين،

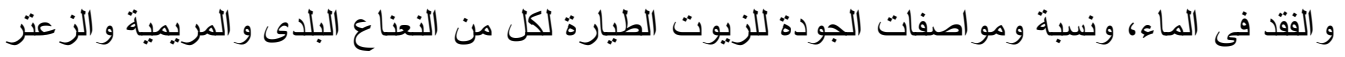

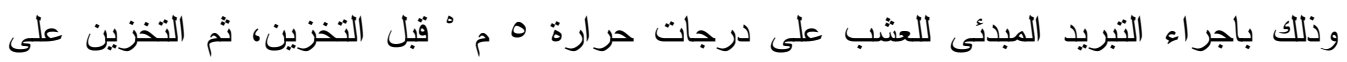

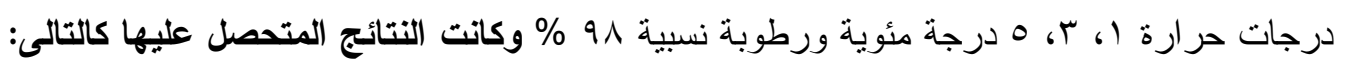

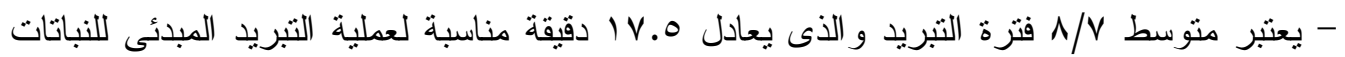
موضوع الدراسة (النعناع و المريمية و الزئز عنر ).

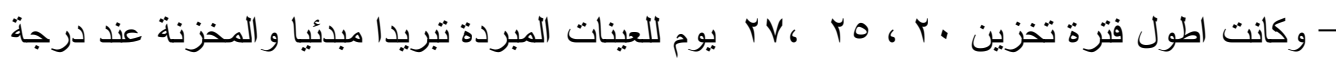

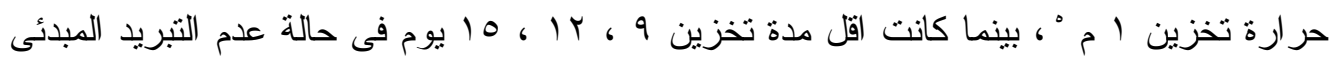

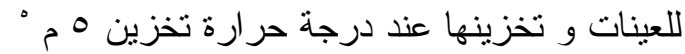

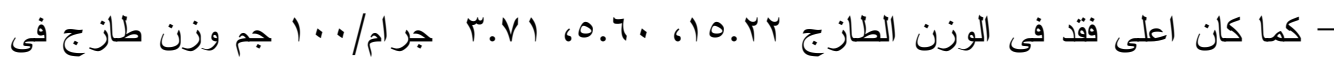

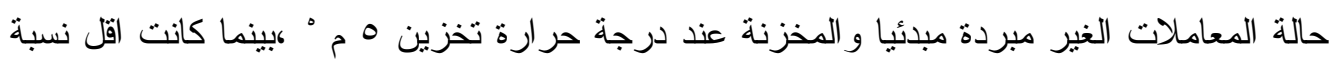

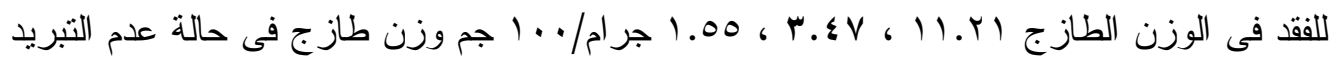

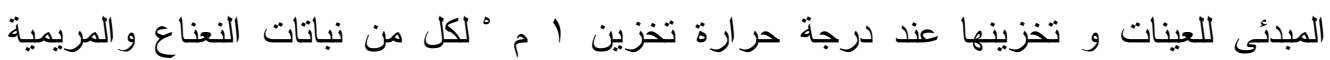
و الزعتر على النزتيب.

- يوجد تأثير طفيف لعملية التبريد المبدئى ودرجة حرارة التخزين على محتوى العشب من

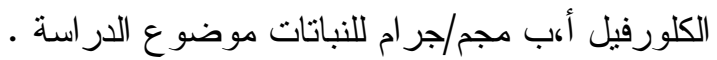

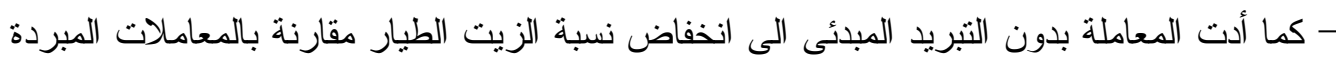

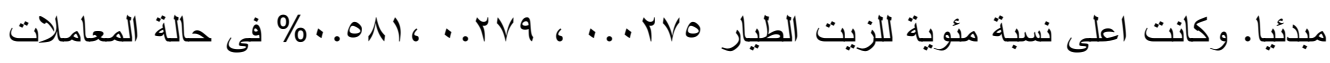

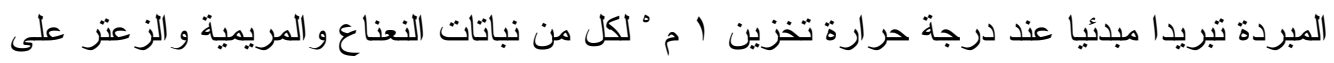

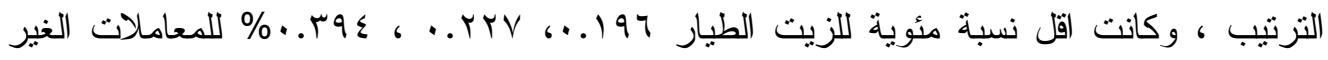

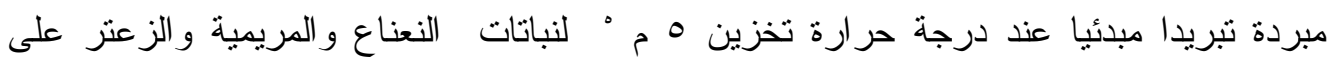
الترنيب

- أدت المعاملة بالتبريد المبدئى عند درجة حرارة تخزين إمْ الى اعلى محتوى من Carvone

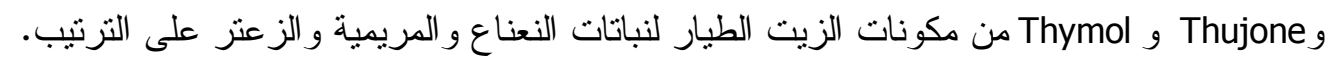

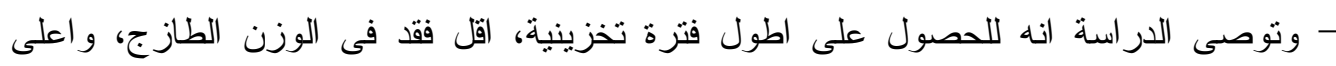

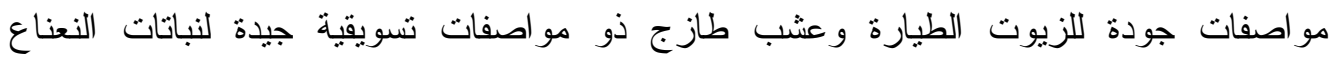

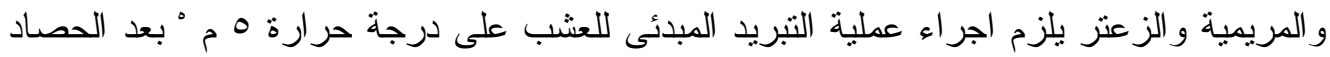

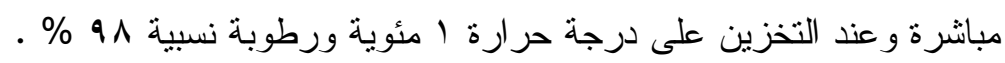

